\title{
Towards a More Strategic Partnership: Strengthening the OSCE through Enhanced EU-OSCE Cooperation
}

\author{
David Galbreath, André Härtel and Stefan Wolff
}

\section{Abstract}

With Europe's security order becoming ever more fragile, the EU and the OSCE face very different political and structural challenges. While the EU's new Strategic Compass emphasizes its aspirations to become a genuine security actor, the OSCE faces erosion of the participating States' consensus on values and weakened executive structures and institutions. Can the OSCE be regenerated through enhanced cooperation with the EU, and if yes, how? In this article, we argue that the accelerated rise of the EU as a security actor should not be achieved at the expense of the OSCE. Rather, cooperation between both organizations should focus on (1) strengthening the OSCE as an autonomous security organization, (2) using the OSCE as a genuine forum for dialogue and mutual assurance, and (3) capitalizing on the main strengths of both organizations while avoiding duplication.

Keywords

OSCE, EU, European security, strategic partnership, inter-organizational co-operation

To cite this publication: David Galbreath, André Härtel and Stefan Wolff, Towards a More Strategic Partnership: Strengthening the OSCE through Enhanced EU-OSCE Cooperation, IFSH (ed.), OSCE Insights 3/2021 (Baden-Baden: Nomos, 2022), https://doi.org/10.5771/978374 8911456-03

\section{Introduction}

The EU and the OSCE find themselves at a critical juncture regarding their role in

* David Galbreath

Department of Politics, Languages and International Studies University of Bath dg341@bath.ac.uk

André Härtel

Department for Political Science

Friedrich Schiller University Jena andre.haertel@gmail.com the European security order. The EU has framed its options for dealing with "new and increasing threats and challenges" in the form of a Strategic Compass that aims to "strengthen a common European security and defence culture" and to "define the right objectives and concrete goals for
Stefan Wolff
Department of Political Science and Interna- tional Studies
University of Birmingham
s.wolff@bham.ac.uk 
[its future] policies". ${ }^{1}$ According to the EU Institute for Security Studies, the purpose of the Strategic Compass is "to provide political direction for the EU's security and defence and improve the Union's operational effectiveness, resilience, capabilities and cooperation with partners". ${ }^{2}$

The OSCE faces a different set of challenges, including deepening internal tensions and a diminishing capacity to fulfil its comprehensive security mandate. ${ }^{3}$ These tensions have led to the erosion of consensus on the norms that have underpinned the OSCE since the 1970s and a weakening of its executive structures and institutions. ${ }^{4}$ This, in turn, has led to a decline in the perceived political value of the Organization and participating States' willingness to expend political and financial capital on it. As Wolfgang Zellner argues, despite the clear need for the OSCE "as an inclusive platform and an actor in settings where other IOs [international organizations] cannot act", ${ }^{5}$ it has become marginalized in the European security order.

While the partnership "basket" of the EU's Strategic Compass offers a fresh opportunity for the EU and the OSCE to consider the nature of their strategic partnership, cooperation between them has a much longer history. Their shared interests and the benefits of cooperation have frequently been stressed by representatives of both organizations. ${ }^{6}$ In its 2016 Global Strategy, the EU formally acknowledged the OSCE "as a Europe-wide organisation [that] lies at the heart of the European security order" and committed to "strengthen[ing] its contribution within and its cooperation with the OSCE as a pillar of European security". ${ }^{7}$ It reiterated its support for the OSCE in its 2019 review of the Strategy. ${ }^{8}$ This shared interest in security and stability has also manifested itself in prioritizing good governance, fighting organized crime, tackling corruption, and acting on the security challenges posed by climate change. ${ }^{9}$

As many scholars have pointed out, however, in reality the two organizations have not taken a joint approach to security issues, tending to work in parallel rather than together. ${ }^{10}$ Despite positive examples to the contrary, such as the cooperation between the current OSCE Special Monitoring Mission to Ukraine and the European Union Advisory Mission in Ukraine, this trend has become stronger and more pervasive. Tensions within the OSCE have grown, and the EU has begun to strive for greater strategic autonomy as a security actor in Europe, especially since the 2007 Treaty of Lisbon. While a more capable and assertive EU can (and should) make more meaningful contributions to European security, we argue that this should not be at the expense of the OSCE. To the contrary, not only is "the OSCE's survival [...] objectively in the EU's best interest", ${ }^{11}$ but a strengthened OSCE would best serve the national interests of the 27 (EU member states) and the 57 (OSCE participating States). ${ }^{12}$

In the following, we propose three building blocks for an improved partnership. The first is a realistic assessment of what enhanced cooperation between the EU and the OSCE can achieve. The OSCE cannot become an instrument of EU security interests alone; it must be 
strengthened as an autonomous security actor with capabilities that differ functionally from those of the EU but are relevant to the management of security challenges in areas of common interest.

Second, the EU needs to understand, use, and strengthen the OSCE as a forum for dialogue and mutual assurance. This requires greater openness to engagement with stakeholders in Russia and countries "east of the EU" on the meaning and interpretation of existing OSCE commitments and on contested concepts such as "sovereignty" and "self-determination", thereby ensuring that the hardening divisions in the European security order do not become permanent. ${ }^{13}$

Third, a clearer focus on converging interests among the 27 and the 57 would translate to a back-to-basics approach that avoids duplication and capitalizes on the main strengths of both organizations across all three dimensions.

We develop this argument in several steps. In the next section, we provide a brief overview of the current state of EU-OSCE cooperation. In section three, we discuss its complementarities and obstacles in light of the academic debate on inter-organizational cooperation. In section four, we conclude with policy recommendations.

\section{The state of EU-OSCE cooperation}

Notwithstanding the EC/EU's commitment to CSCE/OSCE principles, as evidenced in the signing of the Helsinki Final Act (1975), the Charter of Paris (1990), and the Charter for European Se- curity (1999), cooperation was not taken up in earnest as a topic until the early 2000s, on the basis of the OSCE's "Platform for Co-operative Security" (1999) ${ }^{14}$ and the European Council's conclusions on "EU-OSCE Cooperation in Conflict Prevention, Crisis Management and PostConflict Rehabilitation" (2003). ${ }^{15}$ The latter highlighted the need to "avoid duplication" and to work towards "effective complementarity", singling out fact-finding missions, in-field coordination, and reciprocal diplomatic support as cooperation priorities. ${ }^{16}$

Since 2006, the EU has been accorded a formal role within the OSCE: "At the meetings of the decision-making bodies, the European Commission shall have one seat next to the participating State holding the EU Presidency" and "may take the floor immediately after [that state]" ${ }^{17}$ This was further formalized at the interservice level in 2018 in an exchange of letters between the Secretaries General of the OSCE, the European Commission, and the European External Action Service, in which both organizations committed to regular consultations and operational cooperation in areas of common interest. ${ }^{18}$ In addition, the High Representative of the Union for Foreign Affairs and Security Policy and Vice-President of the European Commission usually attends the annual OSCE Ministerial Council meeting in December.

The work of the EU at the OSCE is managed by the Union's Delegation to the International Organizations in Vienna, where seven staff members are dedicated to specific OSCE institutions or topical dimensions. ${ }^{19}$ In addition, the 
European Council has a Working Party on the OSCE and the Council of Europe, which handles the EU's relations with these two organizations and coordinates member states' common positions on debates in both organizations. ${ }^{20}$

As for the OSCE, its participating States have been unable to reach consensus on the establishment of a liaison office in Brussels. In Vienna, the External Co-operation Department of the Office of the Secretary General and a Senior External Co-operation Officer (for all Brussels-based institutions) are responsible for OSCE-EU relations. The OSCE's lack of more direct liaison structures, especially in field missions, has made the systematic coordination of activities with Brussels difficult.

Until recently, both organizations have opted for flexibility with respect to the format of cooperation, with irregular meetings of the EU and OSCE Troikas, meetings between the OSCE Secretary General and the High Representative of the Union for Foreign Affairs and Security Policy, and annual staff-level meetings. The 2018 exchange of letters identified areas of common interest that reflect almost the entire spectrum of OSCE activities, including conflict prevention and mediation, the fight against terrorism, and promotion of the rule of law and good governance. This makes agenda-setting and strategic prioritization difficult. The difficulty is further compounded by the fluctuation of high-level personnel on both sides and structural incompatibilities, which make it hard to identify the right interlocutors and to establish effective relationships between them.

\section{Complementarities and obstacles}

Research on inter-organizational cooperation has found that resource exchange is the main incentive for cooperation among organizations. International organizations cooperate because they are interested in, or depend on, the specific material (project funds, infrastructure, personnel) or immaterial goods (legitimacy, expertise, reputation) the respective partner can provide. ${ }^{21}$ Resource exchange is thus based on complementary interests between cooperating organizations. Policy convergence can also be an important trigger for cooperation and resource exchange.

The EU has become a key source of funding for the OSCE in areas where EU interests and OSCE needs converge. The EU is by far the main contributor to the OSCE's Special Monitoring Mission to Ukraine, providing personnel, equipment, and satellite imagery. ${ }^{22}$ With its network of delegations in the OSCE area, it is also able to provide tailor-made support to OSCE field missions.

The OSCE, for its part, has significant (albeit currently diminishing) convening and agenda-setting power, expertise and tools for conflict prevention, experience in quiet diplomacy, and a genuinely multilateral conflict-related mandate. Compared to the EU, which is not perceived as a neutral actor in the OSCE region's protracted conflicts, the OSCE is more likely to be accepted as a mediator and/or monitor on the ground. Notwithstanding the current political divisions between the OSCE's participating States, the organization remains one of the few pan- 
European dialogue fora and is therefore useful to the EU in the context of institutionalized interaction with Russia on security issues and beyond. In the field the OSCE still commands superior expertise in comparison with the EU, concerning, for example, conflict mediation. OSCE field missions can assist the EU, for example in identifying the positions and needs of national minorities. Finally, the OSCE can be a link, via its Central Asian participants, for the implementation of the EU's Central Asia Strategy.

Cooperation presupposes the existence of certain conditions beyond the resource needs of an organization, however. Among them are the preferences of member states, the power asymmetries between the latter and the organization, the culture and openness of the organization, the role of inter-organizational learning or previous "cooperation paths", and the impact of powerful third parties. ${ }^{23}$ Among the obstacles to a more active partnership between the EU and the OSCE is their asymmetry in terms of power, budget, and structural characteristics. The EU is not an international organization per se. It commands multibillion-euro budgets, and its institutions have considerable agency. Even in its foreign affairs, the Union increasingly deviates from inter-governmental decisionmaking. On the opposite end of the spectrum, the OSCE is a more fragmented organization, with a cumbersome legal status, mandatory consensus in decisionmaking, and an annual budget of just under $€ 140$ million. ${ }^{24} \mathrm{~A}$ major consequence of this asymmetric relationship is the OSCE's understandable fear (shared by significant participating States) of being pushed into a dependent role by the EU or of becoming a tool of EU foreign and security policy.

Further ambivalence arises from membership, mandates, and aspirations. Although the OSCE includes all twenty-seven EU member states, it also includes Russia, all other post-Soviet countries, the US, Canada, Norway, and the UK. ${ }^{25}$ With much more variety in terms of regime types and foreign policy orientations, the OSCE lacks the coherence (and hence the political and economic leverage) of the EU and understands itself more as a "forum" than a full-fledged international organization. ${ }^{26}$ For effective cooperation, EU member states must therefore distinguish between their preferences as EU members and as OSCE participating States. If the EU does not treat the OSCE as a security organization in its own right, closer EU-OSCE cooperation, and thus a more visible EU presence and influence in the OSCE, will be unacceptable to Russia and other non-EU participating States.

Concerning mandates and aspirations, the EU has significantly and increasingly invested in becoming a security organization. By contrast, the OSCE is struggling to remain relevant in its core fields of conflict prevention and mediation, pursuing issues on which all participating States can agree but which are marginal to its mandate and could be more effectively addressed in other arenas. This raises questions about the extent to which the EU needs the OSCE at all in pursuing its own interests and whether inevitable 
duplications may contribute to the further marginalization of the OSCE.

Finally, successful cooperation between international organizations depends on careful relationship management, especially with respect to overlap in membership. This means developing a genuine vision of cooperation, convening on a regular basis, and designing the processes of interaction. ${ }^{27}$ Relationship management between the EU and the OSCE remains a work in progress. The current relationship is under-institutionalized, and even after the 2018 exchange of letters, top officials admit that further efforts are needed. Indeed, there seems to be no straightforward design for cooperation, for example linking the different OSCE entities with the Commission's capabilities and funding instruments of conflict prevention and management. Moreover, the list of specific cooperation areas is incoherent and overly long; identifying priorities and clear benchmarks would therefore make sense. Another critical aspect is the oft-applauded everyday informal cooperation, for which there is little actual evidence in contrast to the frequent duplication and parallel work documented in the research. ${ }^{28}$ A more promising avenue for relationship management is the role that Helga Schmid could play as former Secretary General of the EEAS and current Secretary General of the OSCE, functioning as a genuine "boundary spanner" and enabling the two organizations to cooperate more effectively.

\section{Policy recommendations: Areas for enhanced cooperation}

Building on our proposed three building blocks for improved partnership, we recommend seven steps that the OSCE and its participating States and the EU and its member states could take to enhance their cooperation. Together, they constitute a new approach that (1) is based on a realistic assessment of what enhanced cooperation between the EU and the OSCE can achieve; (2) is characterized by a greater degree of openness on the part of the EU to engage with stakeholders in Russia and countries "east of the EU" within the OSCE context; and (3) avoids duplication, capitalizing on the main strengths of both organizations across all three dimensions.

\section{a) Strengthening prevention}

The EU and the OSCE have different but partially overlapping strengths regarding conflict prevention. The EU has better developed structural prevention instruments, while the OSCE has the track record and capacity to deal with direct prevention but often lacks the financial resources to act swiftly. Enhanced cooperation could thus take the form of greater integration of prevention strategies and their operationalisation. The OSCE could help the EU to define better and more precise prevention-related benchmarks in its various strategies, action plans, and programmes. In turn, the EU should upscale its financial support (for example through its Neighbourhood, Development and International Cooperation 
Instrument) to enable multi-annual OSCE budgets. This could focus on intensifying cooperation in confidence-building measures in the context of the OSCE region's protracted conflicts and on the High Commissioner on National Minorities.

\section{b) Reprioritizing arms control}

Once a cornerstone of OSCE activity and success, arms control norms and mechanisms have eroded as tensions within the Organization have increased and conflicts have escalated to violence. The OSCE Structured Dialogue on current and future challenges and risks to security in the OSCE area, launched by OSCE foreign ministers at the Ministerial Council in Hamburg in December 2016, has the potential to make a crucial contribution to restoring an effective arms control regime. AnEU contribution to strengthening the effectiveness of the Structured Dialogue could include greater preparedness to discuss it in EU fora, including in the European Union Military Committee and the Political and Security Committee. In turn, EU experts could take part in informal working groups and expert-level meetings of military representatives in the framework of the Structured Dialogue, thereby demonstrating the Union's political and diplomatic support.

\section{c) Facilitating connectivity}

The EU and the OSCE each have connectivity agendas. Within the OSCE region "east of the EU", the Eurasian Economic
Union represents an alternative to the EU's political and economic integration project. Moreover, China's Belt and Road Initiative offers a third vision of connectivity. EU-OSCE cooperation could offer an opportunity to address competition between the different integration projects and to begin to work out basic rules that would facilitate greater compatibility. The EU could support OSCE efforts to articulate a coherent Connectivity 2.0 agenda $^{29}$ aimed at contributing to a sustainable and inclusive post-pandemic recovery. As connectivity is increasingly also a security issue, the 27 and the 57 have very clear common interests when it comes to the nexuses between climate and security, technology and security, and governance and security. EU-supported OSCE initiatives that foster confidence building in the economic and environmental dimension - for example in the Caspian, Black, and Mediterranean Seas - could serve as access points to critical regions, generate tangible benefits for the local populations, and eventually become a path towards an inclusive and constructive debate on hard security issues.

\section{d) Countering norm erosion}

The OSCE's comprehensive security concept rests on foundations agreed upon by the participating States in Helsinki in 1975 and Paris in 1990 and was reaffirmed in the 2010 Astana Commemorative Declaration. As these foundations have come under increasing attack over the past decade, EU-OSCE cooperation should focus on building alliances of norm- 
defending states active in both organizations and reflecting a balance of opinions across the 27 and the 57. This could take the form of a "Group of Friends" that includes both EU and non-EU participating States east and west of Vienna and/or focus on specific OSCE institutions, such as the High Commissioner on National Minorities.

\section{e) Intensifying on-the-ground cooperation}

The EU has delegations in all OSCE participating States, and the OSCE currently has operations in thirteen participating States (all "east of the EU"). Nevertheless, cooperation is often ad hoc, extends only to political support, and rarely offers a sustainable source of financing for under-resourced and over-stretched OSCE presences on the ground. Hence, establishing and consolidating links between EU delegations, EU Special Representatives, and member states' embassies, on the one hand, and OSCE missions, Special Representatives of the Chairperson-in-Office, and other field presences, on the other, should become a priority area of EU-OSCE cooperation. This could focus on education-related and other youth-focused initiatives.

\section{f) Increasing knowledge exchange and joint training opportunities}

The creation of a joint EU-OSCE pool of civilian experts and organizing joint training sessions would facilitate "inter-deployability" and a mutual understanding of each organization's institutional culture. Possibilities that could be explored include increased support by the EU or individual member states for the OSCE Academy in Bishkek or in-kind contributions from EU member states for pre-deployment training of OSCE staff. The latter could be modelled on the pre-deployment training courses for the Special Monitoring Mission to Ukraine run by the Austrian Armed Forces International Centre. ${ }^{30}$

\section{g) Utilizing Track 2/Track 1.5 initiatives}

The above recommendations could be strengthened by more systematic support from both organizations for Track 2 or Track 1.5 initiatives to explore views and perceptions across a broader range of participating States on the forms that enhanced EU-OSCE cooperation might take, the specific expectations of the 27 and the 57 , and the red lines for non-EU participating States. This would be in keeping with our key assumption that any discussion of EU-OSCE cooperation must focus on strengthening the OSCE as the primary comprehensive and cooperative security organization in the Euro-Atlantic and Eurasian area.

\section{Notes}

European External Action Service, "Towards a Strategic Compass", May 2021, https://eeas.europa.eu/sites/default/files/t owards_a_strategic_compass.pdf 
European Union Institute for Security Studies, "Finding direction with a Strategic Compass? Reflections on the future of EU security and defence", 2021, p. 2, https://www.2021 portugal.eu/media/5e3 pjuwv/event-report-strategic-compass.pdf

Thomas Greminger, "Making the OSCE More Effective: Practical Recommendations from a Former Secretary General”, IFSH (ed.), OSCE Insights 1/2021, Baden-Baden: Nomos, 2022, https://doi.o rg/10.5771/9783748911456-01

Global Europe Program Working Group on the Future of the OSCE, "Uncommon Cause: The Future of the OSCE", in: TransAtlantic 2/2021, pp. 2-4, https://ww w.wilsoncenter.org/sites/default/files/ media/uploads/documents/Uncommon Cause - The Future of the OSCE v2.pdf

Wolfgang Zellner, Using the OSCE More Effectively: Ideas and Recommendations, paper for the Federal Foreign Office, p. 14, https://ifsh.de/file/publication/2021 OSZE-Studie/20210301_USING_THE_O SCE_MORE_EFFECTIVEELY.pdf

6 See, for example, Benita Ferrero-Waldner, "The European Union and the OSCE: Natural Partners in a Networked World", in: IFSH (ed.), OSCE Yearbook 2006, Baden-Baden: Nomos, 2007, 407-409, https://doi.org/10.5771/9783845 201740-404

European Commission, Shared vision, common action: A stronger Europe (A global strategy for the European Union's foreign and security policy), June 2016, pp. 33-34, https://eeas.europa.eu/archives /docs/top_stories/pdf/eugs_review_web.p df

See European Commission, cited above (Note 7); European Union, The European Union's Global Strategy: Three years on, looking forward, 2019, https:/ /eeas.europa.eu/sites/eeas/files/eu_global_ strategy_2019.pdf

9 See, for example, European External Action Service and European Commission,
20 deliverables for 2020: MonitoringState of Play in February 2020, February 2020, https://ec.europa.eu/neighbourhoo d-enlargement/sites/default/files/monitor ing_spring_2020_20_deliverables_for_20 20.pdf

10 Hylke Dijkstra et al., “The EU's Partners in Crisis Response and Peacebuilding: Complementarities and Synergies with the UN and the OSCE", in: Global Affairs 2-3/2018, 185-196; David Galbreath, "Convergence Without Cooperation? The EU and the OSCE in the Field of Peacebuilding”, in: Steven Blockmans/Jan Wouters/Tom Ruys (eds.), The European Union and Peacebuilding: Policy and Legal Aspects, The Hague: Asser Press, 2010, 175-194.

11 Alyson J. K. Bailes/Jean-Yves Haine/ Zdzislaw Lachowski, "Reflections on the OSCE-EU Relationship”, in IFSH (ed.), OSCE Yearbook 2007, Baden-Baden: Nomos, 2008, 65-77, https://ifsh.de/file -CORE/documents/yearbook/english/07/ BailesHaineLachowski-en.pdf, p. 76

12 See also Deutscher Bundestag, Antrag der Fraktionen CDU/CSU, SPD, FDP und BÜNDNIS 90/DIE GRÜNEN: 45 Jahre Schlussakte von Helsinki, 30 Jahre Charta von Paris - Die Organisation für Sicherheit und Zusammenarbeit in Europa für künftige Aufgaben stärken, Deutscher Bundestag Drucksache 19/19140, 2020, https://dip21.bun destag.de/dip21/btd/19/135/1913551.pdf

13 This is particularly important in light of the June 2021 EU Council Decision not to resume EU-Russia summits, contrary to a joint French and German proposal to do so in order to put EU-Russia relations on a similar footing to US-Russia relations after the Putin-Biden meeting in Geneva on 17 June 2021. While the opportunities that the OSCE offers as a forum cannot replace direct EU-Russia dialogue, EU-Russia bilateral relations should not prejudice relations with Russia within the multilateral context of the 
OSCE, which provides one of the few remaining opportunities for institutionalized dialogue that involves Russia, the $\mathrm{EU}$, and all of its member states.

14 See OSCE, Istanbul Document 1999 (Charter for European Security and Istanbul Summit Declaration), PCOEW389, 1999, 43-45, https://www.osce.org/mc/39 569

15 Council of the European Union, Draft Council Conclusions on EU-OSCE Cooperation in Conflict Prevention, Crisis Management and Post-Conflict Rehabilitation, Doc. No. 14527/1/03, 10 November 2003, https://data.consilium.europa.e u/doc/document/ST-14527-2003-REV-1/e $\mathrm{n} / \mathrm{pdf}$

16 Ibid., p. 2.

17 OSCE, Rules of Procedure of the Organization for Security and Co-operation in Europe, MC.DOC/1/06, 1 November 2006, pp. 8, 10, https://www.osce.org/file s/f/documents/5/0/22775.pdf

"First EU-OSCE high-level meeting takes place in Brussels", European External Action Service, 12 December 2018, https:/ /eeas.europa.eu/headquarters/headqua rters-homepage/55370/first-eu-osce-hi gh-level-meeting-takes-place-brussels en. See also: "Strengthening OSCE-EU Co-operation Discussed at First Annual High-Level Meeting Held in Brussels", OSCE, 13 December 2018, https://www .osce.org/secretary-general/406682

19 See "Organisation for Security \& Co-operation in Europe (OSCE)", Delegation of the European Union to the International Organisations in Vienna, https://ee as.europa.eu/delegations/vienna-internati onal-organisations/2297/organisation-sec urity-co-operation-europe-osce

20 See "Working Party on the OSCE and the Council of Europe", European Council, Council of the European Union, https://www.consilium.europa.eu/en/c ouncil-eu/preparatory-bodies/working-pa rty-osce-and-council-of-europe/
21 Michael F. Harsch, The Power of Dependence: NATO-UN Cooperation in Crisis Management, Oxford: Oxford University Press, 2015.

"The EU provides further satellite imagery support to the OSCE Special Monitoring Mission in Ukraine”, European Commission, 24 March 2017, https://ec. europa.eu/commission/presscorner/detail /es/IP_17_729

23 Rafael Biermann/Joachim A. Koops, "Studying Relations Among International Organizations in World Politics: Core Concepts and Challenges", in: Rafael Biermann/Joachim A. Koops (eds.), The Palgrave Handbook of Inter-Organization Relations, London: Palgrave MacMillan, 2017, 1-46, p. 22.

24 This excludes the operating costs of the OSCE Special Monitoring Mission to Ukraine.

25 A further complication for EU-OSCE cooperation, with particular relevance to the first dimension, arises from the fact that twenty-six of the EU's member states are also members of NATO, whose thirty members are all members of the OSCE.

26 Philip Remler, "The OSCE as Sisyphus: Mediation, Peace Operations, Human rights", IAI Papers 21/16, Istituto Affari Internazionali, April 2021, https://www.i ai.it/sites/default/files/iaip2116.pdf

27 Barbara Gray, "Intervening to Improve Inter-organizational Relationships", in: Steve Cropper/Mark Ebers/Chris Huxham/Peter Smith Ring (eds.), The Oxford Handbook of Inter-organizational Relations, Oxford: Oxford University Press, 2008, 664-690.

28 See Dijkstra et al., cited above (Note 10) and Galbreath, cited above (Note 10).

C.f. Stefan Wolff, "China: A Challenge or an Opportunity for the OSCE?”, Security and Human Rights Monitor, 22 April 2021, https:/www.shrmonitor.org/ china-a-challenge-or-an-opportunity-for-t he-osce-shrm/ 
30 Established in 2014, this programme has trained around 1,000 monitors to date and has been extended to continue until 2022. See "OSCE Secretary General, high-level OSCE officials mark fifth anniversary of AUTINT-run pre-deployment training for Special Monitoring Mission to Ukraine in Götzendorf, Lower Austria”, OSCE, 12 June 2019, https:// www.osce.org/secretary-general/422819 
